\title{
Fever in returning travellers due to a noninfectious disease: Two case reports
}

\author{
Saul Miller MD ${ }^{1}$, Kevin Gabel MD ${ }^{1}$, Christine H Lee MD FRCPC ${ }^{1,2,3}$
}

\begin{abstract}
S Miller, K Gabel, CH Lee. Fever in returning travellers due to a noninfectious disease: Two case reports. Can J Infect Dis Med Microbiol 2008;19(3):253-255.
\end{abstract}

Each year, increasing numbers of people from developed countries travel to developing countries. It is not rare for these travellers to experience illness during or following their trips. It has been estimated that fever is present in $25 \%$ of those who seek medical attention following travel. In the majority of cases, the focus of the investigations centre around an infectious etiology, which can lead to a delay in establishing the noninfectious cause of fever. Two cases of fever, which were due to a noninfectious disease, are reported in returning travellers.

\section{Fièvre d'origine non infectieuse au retour d'un voyage : Deux rapports de cas}

\begin{abstract}
Chaque année, un nombre croissant d'habitants de pays industrialisés se rendent dans des pays émergents. Il n'est pas rare que ces voyageurs deviennent malades durant leur séjour à l'étranger ou à leur retour. On estime que la fièvre se manifeste chez $25 \%$ de ceux qui consultent un professionnel de la santé au retour d'un voyage. Dans la majorité des cas, les analyses diagnostiques sont axées sur une étiologie infectieuse qui peut entraîner un retard à diagnostiquer l'origine non infectieuse d'un épisode fébrile. Le présent article fait le point sur deux cas de pyrexie attribuable à une maladie non infectieuse.
\end{abstract}

Key Words: Fever; Noninfectious; Returning traveller

Cvery year, more than 500 million people travel between Countries, and 50 million people travel from developed countries to developing countries. Fever is a common symptom, and it is present in approximately $25 \%$ of those who seek medical attention following travel. In most cases, investigations centre on elucidating an infectious etiology. When fever is due to noninfectious causes, there may be significant delays in making the correct diagnosis and instituting appropriate therapy. Two cases are presented - one with an acute course and one of a longer duration - highlighting the point that noninfectious diseases can play a role in mimicking infectious causes after travel.

\section{Case 1}

\section{CASE PRESENTATIONS}

A 63-year-old Vietnamese man presented with fever, chills and nonbloody diarrhea three days after returning from a threemonth trip to Vietnam. He developed fever, chills and rigors three days before presentation. The diarrhea had started 10 days prior, and it was accompanied by nausea and nonbloody emesis. He had spent time in both rural and urban settings, and reported no significant exposures, unusual activities, drugs or sexual activities. His immunizations were up to date; he was taking no medications and had not used antimalarial chemoprophylaxis. His past medical history was significant for untreated hepatitis $C$, genotype $1 \mathrm{~b}$, which was acquired from a blood transfusion.

On physical examination, the patient had a temperature of $39^{\circ} \mathrm{C}$, but had no other abnormalities. Investigations revealed a hemoglobin level of $122 \mathrm{~g} / \mathrm{L}$, with a mean corpuscular volume of $108 \mathrm{fL}$; and a white blood cell count of $3.8 \times 10^{9} / \mathrm{L}$, with a granulocyte level of $0.9 \times 10^{9} / \mathrm{L}$ and a platelet level of $108 \times 10^{9} / \mathrm{L}$. The international normalized ratio was 1.2 , and partial thromboplastin time was $32 \mathrm{~s}$. The patient's electrolyte levels; renal function; liver enzyme, bilirubin, glucose, albumin and pancreatic enzyme levels; thyroid function tests; and vitamin $B_{12}$ and folate levels were normal. His electrocardiogram, chest $\mathrm{x}$-ray, and abdominal ultrasound and $\mathrm{x}$-rays were also normal. The patient's urinalysis was bland; four sets of blood films were negative for malaria, and his tuberculosis skin test was nonreactive. Stool cultures and three sets of blood cultures were negative.

The patient was started on intravenous ciprofloxacin and cefotaxime. Over the next two days, he defervesced, but required oxygen to maintain his saturations. A repeat chest $\mathrm{x}$-ray showed a left-sided pleural effusion and left lower lobe atelectasis. Antibiotics were switched to intravenous levofloxacin and vancomycin. He subsequently became tachycardic and hypotensive, and went into respiratory distress requiring intubation, mechanical ventilation and vasopressor support. A high-resolution computed tomography scan of the chest, abdomen and pelvis revealed bilateral pleural effusions with atelectasis, multifocal patchy airspace disease and a small amount of free fluid in the abdomen. Repeat bloodwork revealed a hemoglobin level of $95 \mathrm{~g} / \mathrm{L}$; a white blood cell count of $16.7 \times 10^{9} / \mathrm{L}$, with a granulocyte count of $10.6 \times 10^{9} / \mathrm{L}$ and a platelet count of $61 \times 10^{9} / \mathrm{L}$. The patient's international normalized ratio rose to 1.9 , and partial thromboplastin time rose to $52 \mathrm{~s}$. Circulating leukemic blasts were visible on the peripheral blood smear. A bone marrow biopsy revealed 50\% blasts and marked

${ }^{1}$ Department of Medicine, ${ }^{2}$ Hamilton Regional Laboratory Medicine, ${ }^{3}$ Department of Pathology and Molecular Medicine, McMaster University, Hamilton, Ontario

Correspondence: Dr Christine H Lee, Department of Pathology and Molecular Medicine, McMaster University, Hamilton Regional Laboratory Medicine, St Joseph's Healthcare, 50 Charlton Avenue East, 424 Luke Wing, Hamilton, Ontario L8N 4A6. Telephone 905-521-6021, fax905-521-6083, e-mail clee@mcmaster.ca

Received for publication October 10, 2007. Accepted February 12, 2008 
TABLE 1

Literature review of fever in returning travellers

\begin{tabular}{|c|c|c|c|c|c|c|}
\hline Reference & $\begin{array}{l}\text { Patients } \\
\text { (n) }\end{array}$ & $\begin{array}{c}\text { Adult }(A), \\
\text { pediatric }(P)\end{array}$ & Country & $\begin{array}{l}\text { Inpatient (I), } \\
\text { outpatient (O) }\end{array}$ & $\begin{array}{l}\text { Travel } \\
\text { destination }\end{array}$ & $\begin{array}{c}\text { Percentage with } \\
\text { noninfectious etiology }\end{array}$ \\
\hline Parola et al (5) & 613 & $A$ & France & I & Tropical & 0.8 \\
\hline Antinori et al (6) & 147 & A & Italy & I & Tropical & 4.8 \\
\hline Klein and Millman (7) & 31 & $\mathrm{P}$ & England & I & Tropical & 3.2 \\
\hline West and Riordan (8) & 162 & $\mathrm{P}$ & England & I & Tropical/subtropical & 0.6 \\
\hline O’Brien et al (9) & 232 & A & Australia & I & All areas & 2.6 \\
\hline Ansart et al (10) & 257 & $A$ & France & $\mathrm{O}$ & Tropical & 0.0 \\
\hline Bottieau et al (11) & 1743 & $A, P$ & Belgium & $\mathrm{I}, \mathrm{O}$ & Tropical & 2.2 \\
\hline Doherty et al (12) & 195 & $A, P$ & England & I & Tropical & 0.5 \\
\hline
\end{tabular}

dysplasia of all cell lines consistent with acute myelogenous leukemia and confirmed by flow cytometry. The patient died of multiorgan failure three days later.

\section{Case 2}

A 49-year-old previously healthy woman presented with fever, fatigue and myalgias two weeks after a seven-day vacation to the Caribbean. She reported intermittent febrile episodes, fleeting myalgias in her arms and legs, decreased energy and generalized weakness since her return. She reported no significant exposures, no unusual activity, no drugs and had a monogamous relationship with her husband of 25 years. Her immunizations were up to date, and she had not received travel advice or used any prophylaxis.

On physical examination, she was afebrile with Medical Research Council grade 4/5 weakness of the hip flexors, dorsiflexors and plantar flexors. The remainder of her neurological examination was unremarkable. Her bloodwork revealed a hemoglobin level of $93 \mathrm{~g} / \mathrm{L}$ and a platelet count of $512 \times 10^{9} / \mathrm{L}$. Her electrolyte levels, renal function, coagulation parameters, thyroid function and creatine kinase levels were normal. The patient's albumin level was $29 \mathrm{~g} / \mathrm{L}$, aspartate aminotransferase level was $40 \mathrm{U} / \mathrm{L}$, alanine aminotransaminase level was $112 \mathrm{U} / \mathrm{L}$, alkaline phosphatase level was $320 \mathrm{U} / \mathrm{L}$ and gammaglutamyl transpeptidase level was $127 \mathrm{U} / \mathrm{L}$. Her electrocardiogram and chest $\mathrm{x}$-ray were normal; abdominal ultrasound revealed mild splenomegaly. The patient's multiple blood cultures were negative; histoplasmosis, coccidioidomycosis and brucellosis antibodies, as well as serology for hepatitis, cytomegalovirus, Epstein-Barr virus, parvovirus, arbovirus and dengue virus were also negative.

The patient continued to have ongoing fatigue and muscle weakness over the next four months While she initially indicated that she had no other accompanying symptoms, on further review, she admitted to night sweats and an unintentional weight loss of $15 \mathrm{~kg}$ three months before travel. Repeat bloodwork showed a hemoglobin of $92 \mathrm{~g} / \mathrm{L}$, with a mean corpuscular volume of $77 \mathrm{fL}$; and a platelet count of $526 \times 10^{9} / \mathrm{L}$. Her serum iron concentration was $4 \mu \mathrm{mol} / \mathrm{L}$, total iron binding capacity was $41 \mu \mathrm{mol} / \mathrm{L}$ and ferritin level was $393 \mu \mathrm{g} / \mathrm{L}$. The patient's liver enzymes had normalized, except for an alkaline phosphatase of $186 \mathrm{U} / \mathrm{L}$; albumin level was $28 \mathrm{~g} / \mathrm{L}$ and C-reactive protein level was $135 \mathrm{mg} / \mathrm{L}$. Twenty-four hour urine analysis revealed $290 \mathrm{mg}$ of protein. The colonoscopy and upper endoscopy did not show any pathology. The patient was started on oral iron supplements.
After three months of treatment, her hemoglobin level was $91 \mathrm{~g} / \mathrm{L}$. The patient reported that her fevers had subsided, but she continued to experience night sweats and fatigue. She had lost an additional $16 \mathrm{~kg}$. Bone marrow biopsy showed changes consistent with myelofibrosis.

\section{DISCUSSION}

Illness after travel is a significant problem. Reviews (1-3) have suggested that $15 \%$ to $37 \%$ of travellers have health impairments after their return, with approximately $10 \%$ of all travellers ultimately seeking physician consultation. Fever is a common symptom in returned travellers, and it can be an important indicator of potentially serious disease. One large series (4) suggested that $28 \%$ of travellers reported fever as their primary reason for seeking care. The evaluation of the febrile returned traveller is often difficult because the infections that travellers acquire are often unusual or unfamiliar to most physicians, and the incubation period of many tropical and nontropical infectious diseases is variable.

The present report describes two cases of febrile returned travellers in which the final diagnosis was elusive and ultimately unrelated to the history of travel. In the first case presentation, a 63-year-old man presented to the emergency department with fever shortly after he had returned from a three-month trip to Vietnam. An aggressive search for an infectious etiology was prompted when initial blood work showed pancytopenia. However, his bone marrow biopsy revealed changes consistent with acute myelogenous leukemia and blast crisis. In the second case presentation, a 49-year-old woman presented with fever, fatigue and myalgias following a seven-day vacation to the Caribbean. Extensive investigation was undertaken, but the diagnosis was delayed by almost one year until the bone marrow biopsy revealed myelofibrosis. Interestingly, both patients defervesced before the final diagnosis was made. Although cultures were negative, this raises the possibility that an infectious agent may have responded to antibiotics in the first case and resolved on its own in the second. Earlier consideration of processes unrelated to travel may have spared the patients unnecessary investigations and possibly altered outcome.

In reviewing the English language literature, there were no published case reports emphasizing the role noninfectious diseases can play in mimicking infectious causes after travel. The data from those case series that provided useful information are summarized in Table 1 (5-12). The prevalence of noninfectious diseases as the cause of fever ranged from $0 \%$ to $4.8 \%$. 
The noninfectious causes identified included four cases of connective tissue disease (9) and one case report each of Reiter's syndrome (5), acute myeloid leukemia (7), Kawasaki's disease (8), erythema nodosum (9) and thyrotoxicosis (9). Malignancy should be considered in the differential diagnosis of fever of unknown origin in the traveller.

A number of large studies $(9,13)$ have generally highlighted malaria, gastroenteritis, dengue fever, typhoid, respiratory tract infections and hepatitis as the most frequent causes of illness. These studies emphasize the importance of the timing of the fever and the destination in guiding diagnosis, as well as

\section{REFERENCES}

1. Bruni M, Steffen R. Impact of travel-related health impairments. J Travel Med 1997;4:61-4.

2. Cossar JH, Reid D, Fallon RJ, et al. A cumulative review of studies on travellers, their experience of illness and the implications of these findings. J Infect 1990;21:27-42.

3. Steffen R, Rickenbach M, Wilhelm U, Helminger A, Schär M. Health problems after travel to developing countries. J Infect Dis 1987;156:84-91.

4. Wilson ME, Weld LH, Boggild A, et al; GeoSentinel Surveillance Network. Fever in returned travelers: Results from the GeoSentinel Surveillance Network. Clin Infect Dis 2007;44:1560-8.

5. Parola P, Soula G, Gazin P, Foucault C, Delmont J, Brouqui P. Fever in travelers returning from tropical areas: Prospective observational study of 613 cases hospitalised in Marseilles, France, 1999-2003. Travel Med Infect Dis 2006;4:61-70.

6. Antinori S, Galimberti L, Gianelli E, et al. Prospective observational study of fever in hospitalized returning travelers and migrants from tropical areas, 1997-2001. J Travel Med 2004;11:135-42. empirical therapy. Thus, the approach to the patient traditionally involves taking a careful travel history with geographical and activity-based assessment.

The cause of fever after travel remains undiagnosed in approximately $25 \%$ of cases $(4,11)$. Fortunately, those patients who have fevers of an unknown cause generally recover uneventfully (11). We highlight that overemphasizing the travel history can sometimes lead the clinician away from establishing the correct diagnosis. Noninfectious causes of fever after travel are not common, but they should be considered once life-threatening, treatable or transmissible infections have been excluded.

7. Klein JL, Millman GC. Prospective, hospital based study of fever in children in the United Kingdom who had recently spent time in the tropics. BMJ 1998;316:1425-6.

8. West NS, Riordan FA. Fever in returned travellers: A prospective review of hospital admissions for a 2(1/2) year period. Arch Dis Child 2003;88:432-4.

9. O'Brien D, Tobin S, Brown GV, Torresi J. Fever in returned travelers: Review of hospital admissions for a 3-year period. Clin Infect Dis 2001;33:603-9.

10. Ansart S, Perez L, Vergely O, Danis M, Bricaire F, Caumes E. Illnesses in travelers returning from the tropics: A prospective study of 622 patients. J Travel Med 2005;12:312-8.

11. Bottieau E, Clerinx J, Schrooten W, et al. Etiology and outcome of fever after a stay in the tropics. Arch Intern Med 2006;166:1642-8.

12. Doherty JF, Grant AD, Bryceson AD. Fever as the presenting complaint of travellers returning from the tropics. QJM 1995;88:277-81.

13. Freedman DO, Weld LH, Kozarsky PE, et al; GeoSentinel Surveillance Network. Spectrum of disease and relation to place of exposure among ill returned travelers. N Engl J Med 2006;354:119-30. (Erratum in 2006;355:967). 


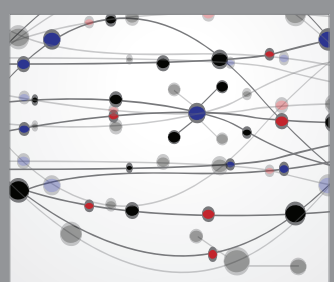

The Scientific World Journal
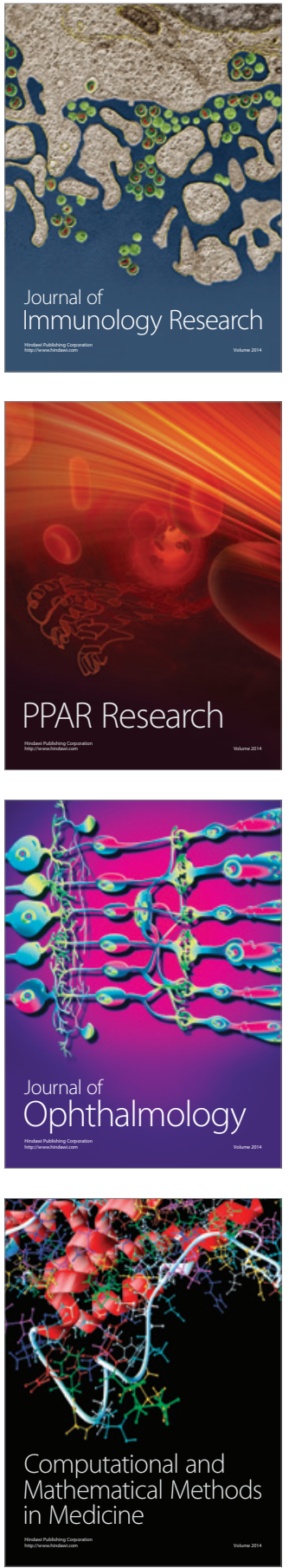

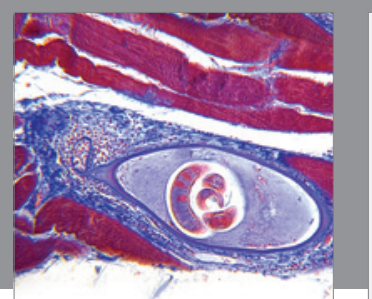

Gastroenterology Research and Practice

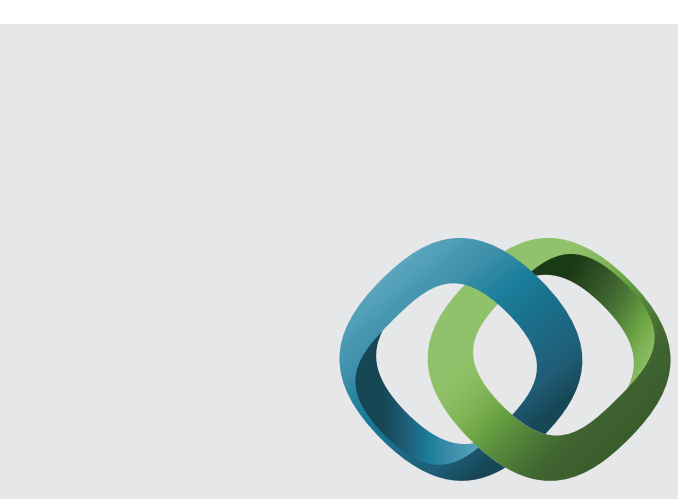

\section{Hindawi}

Submit your manuscripts at

http://www.hindawi.com
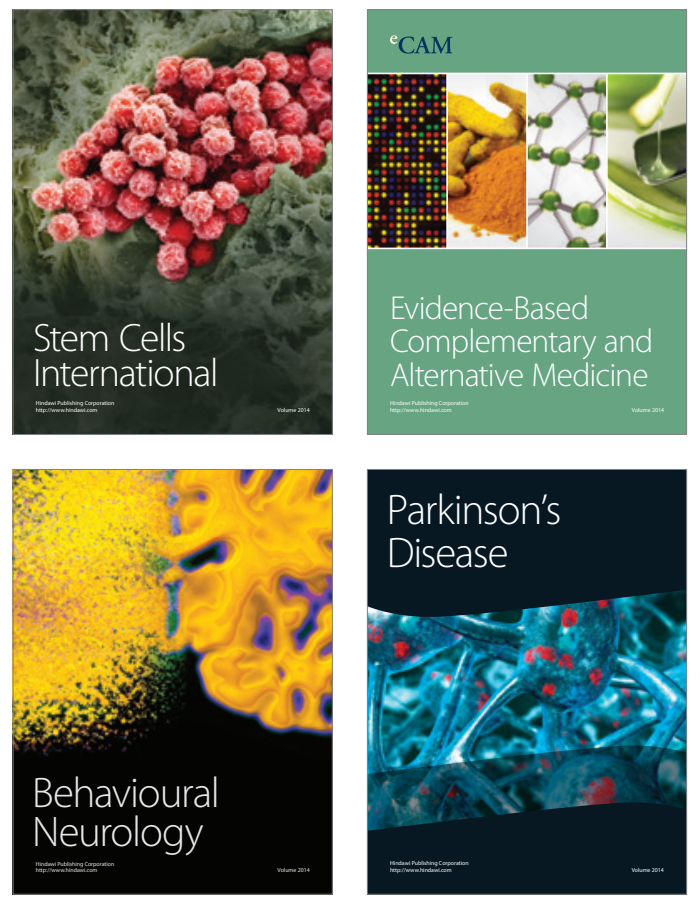
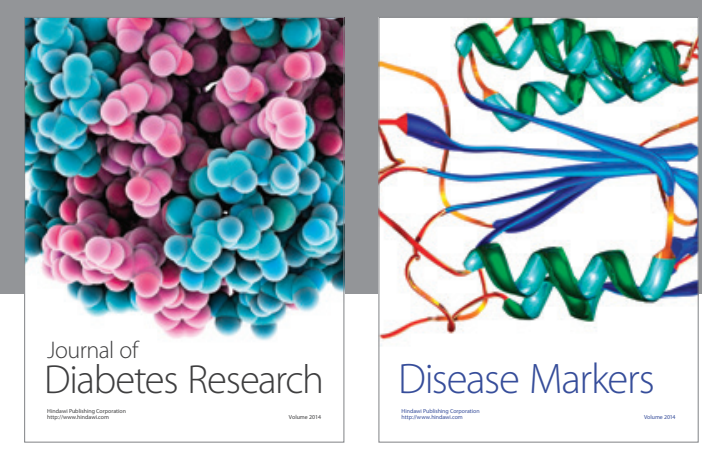

Disease Markers
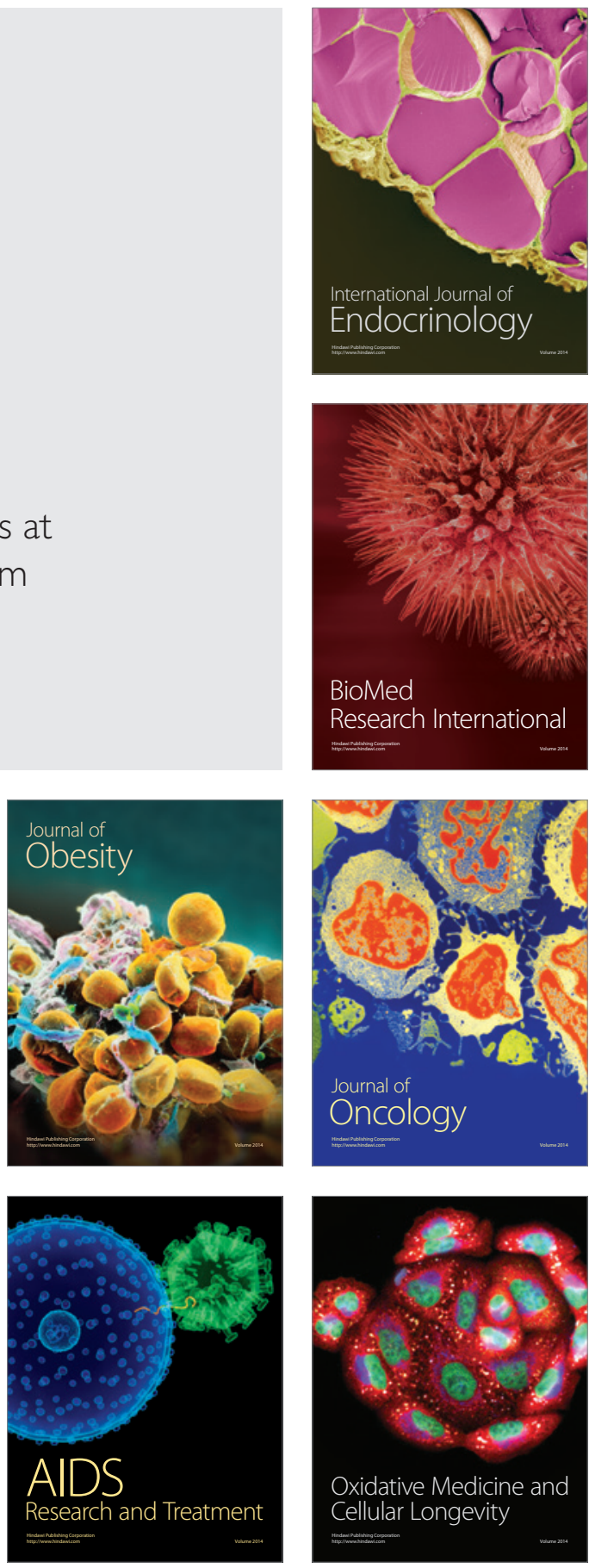